\title{
Explaining the effect of internal marketing on the performance of organization green marketing with the mediating role of resource commitment and internal branding
}

\author{
Kimia Parang ${ }^{1}$, Mehdi Eftekharian ${ }^{2}$ \\ ${ }^{1}$ Ms. in Executive Management, Islamic Azad University, Shiraz, Iran \\ ${ }^{2}$ Ms. in Executive Management, Islamic Azad University, Shiraz, Iran
}

\begin{abstract}
Human capital is one of the vital factors for gaining competitive advantage and creating sustainable value in today's organizations. In the hotel industry, as one of the service industries, this issue is more important. Therefore, the present study was performed to examine the effect of internal marketing on the performance of organization green marketing with the mediating role of resource commitment and internal branding. The research statistical population includes employees of Shiraz metropolitan hotels, from which a sample of 237 people was selected using the Cochran's formula and considering the huge size of the research community. In this study, Vast standard questionnaires was used to collect data, the reliability of which was calculated using Cronbach's alpha coefficient. Also, data analysis was performed using structural equation method. Based on the findings of this study, internal marketing has a direct effect on the performance of green marketing in the organization. In addition, as the results of path analysis show, internal marketing has an indirect effect on the green performance of marketing through resource commitment and internal branding.
\end{abstract}

Keywords: brand, internal marketing, green marketing.

\section{Introduction}

In today's world, service industries and organizations have a significant role in the development of countries' economies. The role of these organizations in the society's economic system is becoming more and more clear and extensive. The insurance industry is rapidly changing and becoming competitive in today's world, and the correct identification of customer needs, satisfying them and innovation in services and products is the prerequisite for success and survival in this competition (Manray, 2009). To this end, the organization needs to have creative and satisfied employees who provide the best services with the highest quality to customers. Marketing researchers have focused on external marketing to promote products and retain customers. Several definitions have been provided on internal marketing in the literature in the last decade (Kim, 2012). The marketing authors have introduced internal marketing as a concept, a philosophy and a management action that is related to human resource management, service marketing or change management. Internal marketing and the use of its principles and tools, is known 
as an introduction to the implementation of external marketing programs and a tool that affects all the strategies of the organization. The effect of adopting an internal marketing approach on employee satisfaction and commitment ultimately leads to facilitating customer satisfaction and organization's excellent performance (Maureen et al., 2015). Achieving this important thing for the organization requires having creative and satisfied employees who provide the best services with the highest quality to customers. Marketing researchers focus on external marketing to promote products and retain customers. There have been many definitions of internal marketing in the literature over the past decade (Kim, 2012). The authors have introduced internal marketing as a concept, a philosophy and a management action that is related to human resource management, service marketing or change management. Internal marketing and the use of its principles and tools is known as an introduction to the implementation of external marketing programs and as a tool that affects all the strategies of the organization.

The effect of adopting an internal marketing approach on employee satisfaction and commitment, which ultimately facilitates customer satisfaction and excellent performance of the organization (Maureen et al., 2015). Internal branding, which has been considered with the emergence of the concept of internal marketing in recent decades, is a process through which employees internalize the desired brand image and motivate customers and other organizational factors to portray it. In addition, the effectiveness of green marketing affects the company's performance in scheduling green marketing programs. This prompted researchers to take a step to fill this gap and strengthen the literature on these concepts and to develop a model for evaluating the factors affecting brand performance based on internal marketing and internal branding. Accordingly, considering the research vacuum in the field of the role of internal marketing on green marketing performance, we seek to answer the main question that what effect does internal marketing on the organization's green marketing performance mediated by resource commitment and internal branding?

\section{Literature and theoretical foundations of research}

\section{2-1. internal marketing}

The concept of internal marketing was first introduced in 1976 by Barry et al. As a way to achieve service quality. They defined the concept of internal marketing based on traditional 4P marketing, including: product, price, location and promotion. The basic premise of Barry et al. (1976) was that employees are the organization's internal customers and their job is the organization's products. In the early 1980s, Grunros introduced employees as an important part of the products and services delivered, which should be trained as marketers with customer retention skills to be able to establish continuous and effective relationships with customers (Zitmal et al., 1996) . Subsequently, in the early 1990s, internal marketing was defined as: "Seeing employees as internal customers and their jobs as internal products and meeting the needs and wants of these customers when they address the goals of the organization." Internal marketing is the process of managing employees as internal customers and projects as internal products that meet their needs and desires and make them more committed to organizational goals. Internal marketing is a set of activities that the human resources department in the organization uses to effectively and efficiently motivate, train and learn 
employees to provide better services to customers (Khodada Hosseini, 2015). Internal marketing can lead employees to higher levels of job satisfaction, the level at which a person can achieve job satisfaction and instill that sense of happiness in other employees who are the same customers within the organization. (Cutler, 2008).

Internal marketing uses traditional marketing tools to create and distribute business products to employees. According to this view, all employees of the organization are its internal customers and should know how they affect customer value through organizational processes (GAO, 2010). Although the concept of internal marketing is related to human resource management, the two concepts are actually separate. Human resource management is a broader concept than internal marketing and internal marketing is recognized as one of the tools of human resource management. Therefore, the purpose of internal marketing is to meet the needs of employees by creating coordinated exchanges between employees and organizations, which is in line with the goals of human resource management of having satisfied and loyal employees (Betis et al., 2010). Numerous studies show that the use of internal marketing is a useful tool to enable the organization to respond effectively to customers and ultimately improve the performance of the organization. The existence of satisfied and capable employees is considered a necessary condition for the development of any organization. Internal marketing seeks to generate such capital (Janook, 2010). Internal marketing is a kind of joint treatment for both customers and employees, which equally facilitates a kind of planning to achieve organizational goals between these two groups. On the other hand, the flexibility and dynamism of organizations in today's environment can lead to strengthening internal marketing and organizational performance. In general, it can be said that the implementation of internal marketing and the creation of strong and deeper organizational entrepreneurship in service organizations, will equip those organizations with competencies and capabilities that, while taking advantage of environmental opportunities, Improving their performance will follow. Internal marketing emphasizes that the success of external marketing is to have motivated, satisfied and innovative employees. Internal marketing is used by companies to enhance employee competencies to meet organizational goals (Kim, 2012). Many researchers agree that the organization should improve quality for domestic and foreign customers.

For sustainable growth, organizations are required to pay attention to the needs of domestic and foreign customers to improve service quality (Chen, 2013). The main purpose of this concept is to turn employees into internal customers and their value was conceived in the organization. This is a turning point for the organization so that its employees have a good understanding of their organization. Second, they need to know that the domestic market as well as domestic suppliers are through working together and ultimately meeting the needs of partners and the organization; The basic idea of internal marketing was based on the principle that providing effective services requires employees to be motivated and aware of customer needs (Amit, 2001), while in service organizations the main role in attracting customers and maintaining relationships with them is the responsibility of employees. (Maureen, 2015). Internal marketing can be considered as the organization's efforts to manage its internal resources in order to 
provide better services to customers. In fact, at the heart of internal marketing lies the concept that employees are the main shaper of the internal market of any organization (Majrova, 2015). Thus, it can be said that the organization is able to meet the needs of foreign customers by satisfying the needs of domestic customers. Internal marketing treats employees as customers who are as important to the organization as external customers. Internal marketing focuses on appropriate internal relationships between people at all levels in the organization. Therefore, a service-oriented and customeroriented approach is created between employees in contact with internal customers, and given that the market-oriented organization is able to better identify the needs and wants of the target market and thus compare with competitors with greater efficiency and effectiveness to customer satisfaction. Achieves (Cheng, 2014).

In recent decades, internal marketing in its broadest sense has been associated with theories of human resource management and organizational performance. According to Glasman and McCaffey (1992), Don \& Barnes (2000) and Verry (2001), considering human resources as internal customers can be the best common ground for internal marketing and human resource functions. The importance of the role of internal marketing in the development of effective human resources (Baker, 1999). The argument of internal marketing is that the first customers of any organization are its employees. According to Barry and Parashorman (1991), internal marketing is the process of managing employees as internal customers and projects and jobs as internal products that meet the needs and desires of customers and cause employees to adhere to organizational goals. . The organization's programs in the service sector should be such that in addition to the foreign market (customers) to the domestic market (employees) is also used. Therefore, internal marketing should be done before external marketing, and today, internal marketing is recognized as a tool to implement the organization's strategies, which promotes organizational competencies and performance by motivating employees.

\section{2-2. Marketing performance}

In the current era, every organization urgently needs an evaluation system in order to be aware of the desirability and quality of its products, especially in complex and dynamic environments (Manray, 2009). One of the most important concepts of any organization in any size and any part is the performance of the organization's market. Marketing performance is the organization's ability to increase sales, improve the company's competitive position, develop new products, improve product quality, reduce the delivery time of goods or services to customers, expand market share compared to other competitors (Kim, 2012). Measures are needed to measure the performance of a marketing system. Marketing metrics are all metrics that measure the performance of a company's marketing system, from advertising programs to distribution channels, behavior, and customer relationships). Measuring and analyzing the performance of marketing activities can play an important role in increasing the role of marketers in setting the organization's macro strategies (Khodad Hosseini, 2015). 


\section{2-3. Green marketing performance}

In the early 1791s, marketing took a product-oriented approach. With the advent of new consumer products and increasing the welfare of society and the efforts of more and more organizations to surpass competitors, the marketing approach has changed to a customercentric approach; But the trend we are facing today is the greater awareness of organizations towards the environment (). Accordingly, the need to protect the environment has caused consumers to rethink the products they buy. Today, many consumers are willing to pay more for products that meet environmental standards for real environmental protection (Majrova, 2015).

Green marketing is the strategic effort of the organization in offering environmentally friendly products to customers. Green marketing includes product modification, changes in production and process methods, packaging and advertising modification. He also believes that green marketing is a tool to promote green products to meet the needs of customers (Cheng, 2014). Sarker (2012) believes that green marketing involves a wide range of activities, including product modification, production process changes, packaging changes, remodeling, and advertising modification. Green marketing strategy helps companies to manage their resources efficiently, which improves the situation of large companies and ultimately leads to improved profitability.

Green marketing strategy helps companies to manage their resources efficiently, which improves the situation of large companies and ultimately leads to improved profitability.

\section{2-4. Commitment of resources}

Resource commitment has been identified as the willingness to provide the materials needed and support to achieve the stated goals of the company (Jaminik, 2014). Resource commitment can be defined as how valuable resources are allocated to achieve the best (Cutler, 2008). Resource commitment allows the company to start its environmental marketing plans on time and increase performance. Leading the way, followers need to invest more resources in their green marketing strategies in order to achieve superior performance (Aragon, 2014).

\section{5-2. Internal branding}

Internal branding with emphasis on improving the perception and behavior of employees as internal customers. In branding Internal It is believed that the first customers of an organization are its employees and strengthen the brand from the perspective Customers in the first place need to strengthen the brand position within the organization and with employees because the first experience of a customer in dealing with frontline employees is formed and is influenced by their behavior and performance (Amit, 2001). Internal branding is a set of strategic processes that coordinate employees and enable them to achieve the right experience for the customer in a sustainable way. These processes include internal communication, training support, leadership activities, recognition and reward programs, recruitment activities, and retention factors. Internal brand management can lead to the creation and development of values by creating situations in which high-level employees identify with the organization and participate effectively in 
branding activities. Internal branding focuses on employees' understanding of brand goals and commitment and fits in with the values of the organization's employees and the brand (Bigliardi, 2012)

\section{6-2. Empirical background of the research.}

The following is the empirical background of the research in Table (1):

\begin{tabular}{|c|c|c|}
\hline $\begin{array}{c}\text { Achievements } \\
\end{array}$ & Research title & Researcher \\
\hline $\begin{array}{l}\text { Brand-centric can directly and indirectly affect } \\
\text { the brand performance of the organization } \\
\text { through customer value creation activities. } \\
\text { Entrepreneurship and marketing ability also } \\
\text { have a positive effect on the brand orientation of } \\
\text { the organization. }\end{array}$ & $\begin{array}{l}\text { Investigating the } \\
\text { Expansion of } \\
\text { Organizational } \\
\text { Performance: The Role } \\
\text { of Brand Orientation in } \\
\text { B2B Marketing } \\
\end{array}$ & $\begin{array}{l}\text { Chang et al. } \\
\text { (2018) }\end{array}$ \\
\hline $\begin{array}{l}\text { The results of this study showed that internal } \\
\text { marketing practices have a positive effect on job } \\
\text { satisfaction and organizational identity and } \\
\text { through these two variables lead to increased } \\
\text { organizational commitment. }\end{array}$ & $\begin{array}{l}\text { Internal marketing and } \\
\text { attitudinal results of } \\
\text { customer-related } \\
\text { employees }\end{array}$ & $\begin{array}{l}\text { Hernandez- } \\
\text { Diaz et al. } \\
\text { (2017) }\end{array}$ \\
\hline $\begin{array}{l}\text { Green innovation and green promotion have a } \\
\text { positive effect on the efficiency of companies. }\end{array}$ & $\begin{array}{l}\text { The Impact of Green } \\
\text { Marketing Strategies on } \\
\text { Company Performance } \\
\text { in Malaysia }\end{array}$ & $\begin{array}{l}\text { Zawahir et al. } \\
\quad(2015)\end{array}$ \\
\hline $\begin{array}{l}\text { Green marketing strategy leads the company to } \\
\text { profitability by optimizing marketing } \\
\text { performance and reducing costs. Also, the } \\
\text { dimensions of organizational outcomes, such as } \\
\text { process performance, are not positively related } \\
\text { to economic success. }\end{array}$ & $\begin{array}{l}\text { Green marketing } \\
\text { strategy and company } \\
\text { performance: The role } \\
\text { of environmental } \\
\text { culture adjustment }\end{array}$ & $\begin{array}{l}\text { Forou et al. } \\
\quad(2011)\end{array}$ \\
\hline $\begin{array}{l}\text { There is a significant relationship between brand } \\
\text { strategy and brand performance and the analysis } \\
\text { of the interfering effect of brand identity in this } \\
\text { regard has been confirmed. }\end{array}$ & $\begin{array}{l}\text { The effect of brand- } \\
\text { centric strategy on } \\
\text { brand performance with } \\
\text { emphasis on brand } \\
\text { identity intervention }\end{array}$ & $\begin{array}{c}\text { Mashdi } \\
\text { Ramadan et al. } \\
\text { (2019) }\end{array}$ \\
\hline $\begin{array}{l}\text { Internal marketing has not had a direct effect on } \\
\text { brand performance, but it does indirectly affect } \\
\text { brand performance through internal branding. } \\
\text { The results of path analysis confirmed the direct } \\
\text { effect of internal branding on brand performance } \\
\text { as well as its indirect effect on performance } \\
\text { through employee commitment to the brand. In } \\
\text { addition, the results showed that internal } \\
\text { marketing does not have a significant direct } \\
\text { effect on brand commitment to the organization }\end{array}$ & $\begin{array}{l}\text { Development of the } \\
\text { organization's brand } \\
\text { performance model } \\
\text { based on internal } \\
\text { marketing and internal } \\
\text { branding }\end{array}$ & $\begin{array}{c}\text { Maleki Min } \\
\text { Bash Ragah } \\
\quad(2016)\end{array}$ \\
\hline $\begin{array}{l}\text { Internal branding did not have a positive effect } \\
\text { on brand commitment but the positive effect of } \\
\text { brand commitment on brand performance was } \\
\text { confirmed. In addition, the results showed that } \\
\text { the effect of internal branding on brand } \\
\text { commitment for employees who work in a more } \\
\text { competitive environment is stronger than }\end{array}$ & $\begin{array}{l}\text { Internal branding and } \\
\text { brand performance in } \\
\text { the bank: the role of } \\
\text { moderator of } \\
\text { competitive climate and } \\
\text { job satisfaction }\end{array}$ & $\begin{array}{l}\text { Azizi and } \\
\text { Twelve (2015) }\end{array}$ \\
\hline
\end{tabular}




\section{Research methodology}

The present research is applied based on the purpose and descriptive and correlational based on data collection. The statistical population of this research is the staff of hotels in Shiraz metropolis. Due to the size of the catering community, the sample size was determined to be 237 using the Cochran's formula. Based on this, sampling was determined randomly. Data collection in this study was measured on library studies and standard questionnaires with a Likert scale from strongly disagree to strongly agree. Accordingly, the standard questionnaire of Lings et al. (2005) was used to measure the variable of internal marketing, and the standard questionnaire of Almgaran et al. (2012) was used to measure the variable of green marketing performance. The reliability of the instrument was calculated using Cronbach's alpha coefficient, which has a desirable reliability considering that its value is more than 0.7 for all research variables. Convergent and divergent validity were also used to assess validity. Data analysis was performed using confirmatory factor analysis and structural equation modeling.

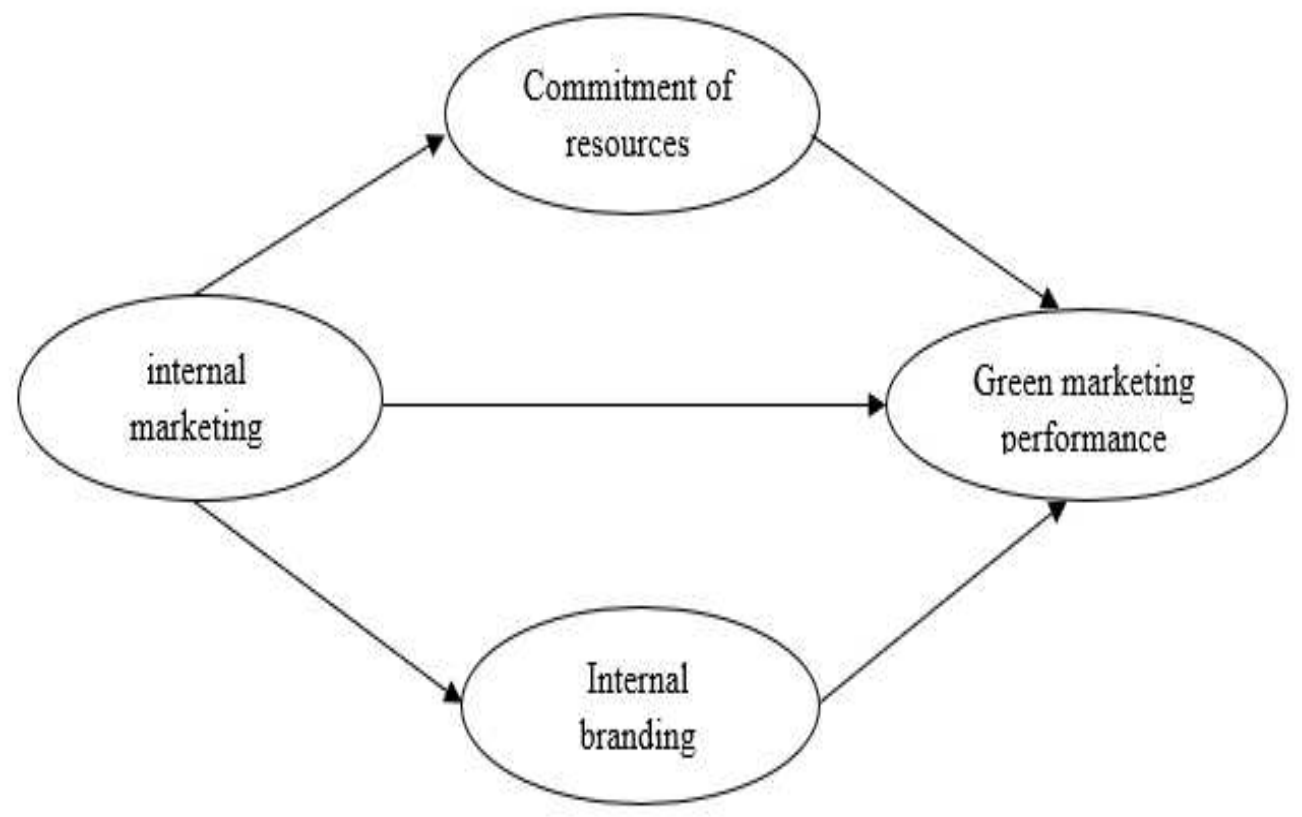

figure 1 . Conceptual model of research

\section{Research findings}

\section{4-1. Research validation}

In this study, Cronbach's alpha and composite reliability methods have been used to measure the reliability of research structures. Also, to evaluate the validity of the structures, convergent validity and divergent validity were used in Warp PLS software. The calculated values are shown in Table (2): 
Table 2. Results of structural validity evaluation of convergent and divergent validity

\begin{tabular}{|c|c|c|c|c|c|c|c|}
\hline AVE & P-value & $\begin{array}{l}\text { Factor } \\
\text { load } \\
\text { values }\end{array}$ & $\begin{array}{l}\text { Composite } \\
\text { reliability }\end{array}$ & $\begin{array}{l}\text { Cronbach's } \\
\text { alpha }\end{array}$ & $\begin{array}{l}\text { Number } \\
\text { of } \\
\text { questions }\end{array}$ & item & Structure \\
\hline $0 / 839$ & $\begin{array}{l}<0 / 001 \\
<0 / 001 \\
<0 / 001 \\
<0 / 001\end{array}$ & $\begin{array}{l}0 / 723 \\
0 / 846 \\
0 / 763 \\
0 / 791\end{array}$ & $0 / 792$ & $0 / 783$ & Y & $\begin{array}{l}\text { D1 } \\
\text { D2 } \\
\text { D3 } \\
\text { D4 }\end{array}$ & $\begin{array}{c}\text { internal } \\
\text { marketing }\end{array}$ \\
\hline $0 / 721$ & $\begin{array}{l}<0 / 001 \\
<0 / 001 \\
<0 / 001 \\
<0 / 001\end{array}$ & $\begin{array}{l}0 / 815 \\
0 / 947 \\
0 / 869 \\
0 / 779\end{array}$ & 0/914 & $0 / 841$ & 11 & $\begin{array}{l}\text { B1 } \\
\text { B2 } \\
\text { B3 } \\
\text { B4 }\end{array}$ & $\begin{array}{l}\text { Internal } \\
\text { branding }\end{array}$ \\
\hline $0 / 733$ & $\begin{array}{l}<0 / 001 \\
<0 / 001 \\
<0 / 001\end{array}$ & $\begin{array}{l}0 / 855 \\
0 / 908 \\
0 / 859\end{array}$ & $0 / 769$ & $0 / 856$ & 7 & $\begin{array}{l}\text { T1 } \\
\text { T2 } \\
\text { T3 }\end{array}$ & $\begin{array}{l}\text { Commitment } \\
\text { of resources }\end{array}$ \\
\hline $0 / 819$ & $\begin{array}{l}<0 / 001 \\
<0 / 001 \\
<0 / 001\end{array}$ & $\begin{array}{l}0 / 934 \\
0 / 781 \\
0 / 891\end{array}$ & $0 / 821$ & 0/798 & 4 & $\begin{array}{l}\text { A1 } \\
\text { A2 } \\
\text { A3 }\end{array}$ & $\begin{array}{c}\text { Green } \\
\text { marketing } \\
\text { performance }\end{array}$ \\
\hline
\end{tabular}

The divergent validity criterion in a structure is that the value of the AVE root must be greater than the degree of correlation of that structure with other structures. The results are shown in the table below.

TableL 3. Correlation results of structures and the square root of AVE

\begin{tabular}{|c|c|c|c|c|}
\hline $\begin{array}{c}\text { Green marketing } \\
\text { performance }\end{array}$ & $\begin{array}{c}\text { Commitment } \\
\text { of resources }\end{array}$ & $\begin{array}{c}\text { Internal } \\
\text { branding }\end{array}$ & $\begin{array}{c}\text { internal } \\
\text { marketing }\end{array}$ & $\begin{array}{c}\text { AVE=0/899 } \\
\text { internal marketing }\end{array}$ \\
\hline & AVE=0/798 & AVE $=0 / 871$ & $0 / 743$ & Internal branding \\
\hline & $0 / 315$ & $0 / 356$ & $\begin{array}{c}\text { Commitment of } \\
\text { resources }\end{array}$ \\
\hline $\mathrm{AVE}=0 / 869$ & $0 / 459$ & $0 / 289$ & $\begin{array}{c}\text { Green marketing } \\
\text { performance }\end{array}$ \\
\hline
\end{tabular}

\section{4-2. Test results of research hypotheses}

Before examining the hypotheses, the model should first be examined in terms of fitness indicators. WarpPLS software calculates model fit using three indicators: APC, AVIF and ARS. The results are shown in Table (4).

Table 4. Results of model fit measurement indicators

\begin{tabular}{|c|c|c|}
\hline The value obtained & Acceptable level & \\
\hline $\mathrm{P}<0 / 0001 \cdot 0 / 315$ & Less than 0.05 & APC \\
\hline $1 / 81$ & $\begin{array}{c}\text { Less than } 5 \text { acceptable } \\
\text { Less than } 3 \text { ideals }\end{array}$ & AVIF \\
\hline $\mathrm{P}<0 / 0001 \cdot 0 / 329$ & Less than 0.05 & ARS \\
\hline
\end{tabular}

Examining the significance level of research hypotheses (p-value) is a significant effect of hypotheses. In this study, considering that the level of significance for all hypotheses is less than 0.05 , the direct and significant effect of all of them is confirmed. 


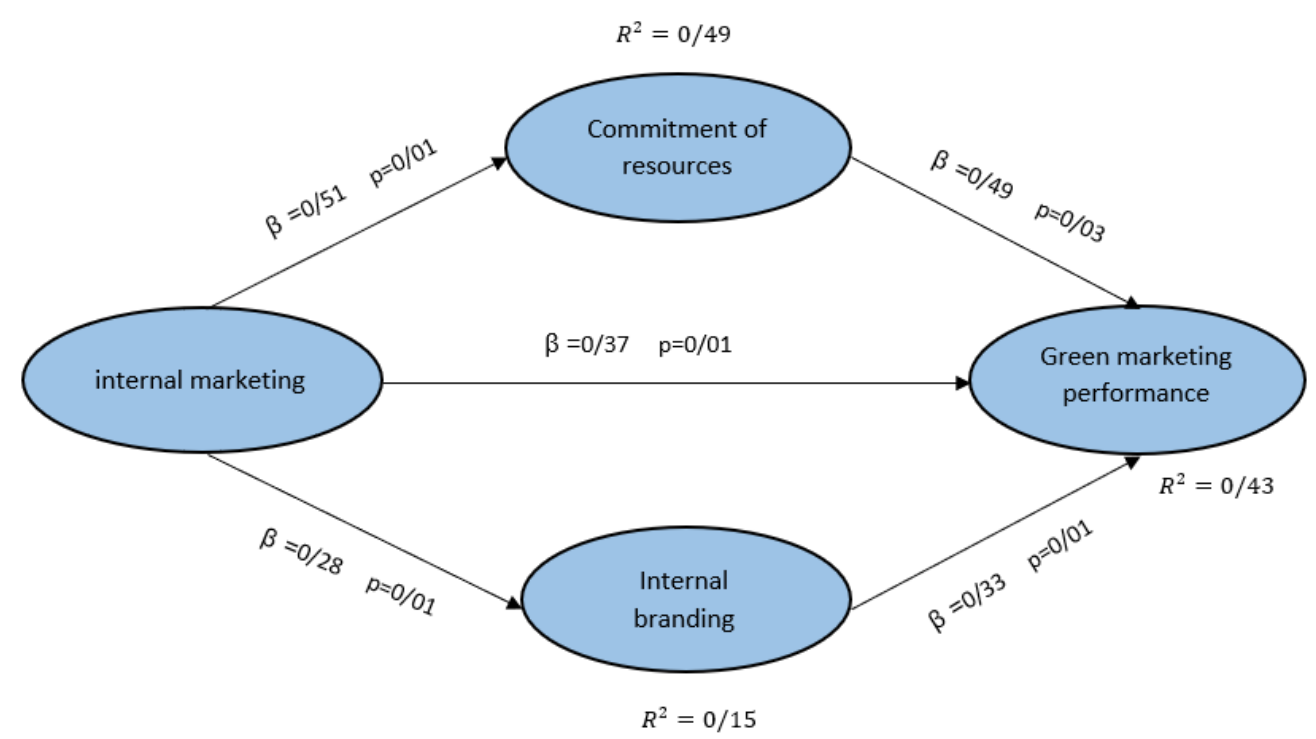

figure 2. Structural equation model results

The results are shown in Table (5):

Table 5. Test results of research hypotheses

\begin{tabular}{|c|c|c|c|c|}
\hline Result & $\begin{array}{c}\text { Significance } \\
\text { level }\end{array}$ & $\begin{array}{c}\text { Path } \\
\text { coefficient } \\
\beta\end{array}$ & Route & \\
\hline Confirmation & $0 / 01$ & $0 / 51$ & $\begin{array}{c}\text { Internal marketing has a positive } \\
\text { and significant effect on resource } \\
\text { commitment }\end{array}$ & $\begin{array}{c}\text { The first } \\
\text { hypothesis }\end{array}$ \\
\hline Confirmation & $0 / 01$ & $0 / 28$ & $\begin{array}{c}\text { Internal marketing has a positive } \\
\text { and significant effect on internal } \\
\text { branding }\end{array}$ & $\begin{array}{c}\text { The } \\
\text { second } \\
\text { hypothesis }\end{array}$ \\
\hline Confirmation & $0 / 01$ & $0 / 37$ & $\begin{array}{c}\text { Internal marketing has a positive } \\
\text { and significant effect on green } \\
\text { marketing performance }\end{array}$ & $\begin{array}{c}\text { The third } \\
\text { hypothesis }\end{array}$ \\
\hline Confirmation & $0 / 03$ & $0 / 49$ & $\begin{array}{c}\text { Resource commitment has a } \\
\text { positive and significant effect on } \\
\text { green marketing performance }\end{array}$ & $\begin{array}{c}\text { The fourth } \\
\text { hypothesis }\end{array}$ \\
\hline Confirmation & $0 / 01$ & $0 / 33$ & $\begin{array}{c}\text { Internal branding has a positive } \\
\text { and significant effect on green } \\
\text { marketing performance }\end{array}$ & $\begin{array}{c}\text { Fifth } \\
\text { Hypothesis }\end{array}$ \\
\hline
\end{tabular}

Then, to examine the magnitude of the causal relationships, the Cohen effect size index was calculated. Because in this way it can be determined that the effect of the path coefficient according to the proposed values is 0.02 (small), 0.15 (medium) and 0.35 (large). Thus, values less than 0.02 are weak and not effective. 
Table 6. Cohen index results

\begin{tabular}{|c|c|l|}
\hline Result & $\begin{array}{c}\text { Effect } \\
\text { size index }\end{array}$ & \multicolumn{1}{c|}{ Route } \\
\hline $\begin{array}{c}\text { Great } \\
\text { impact }\end{array}$ & $0 / 578$ & internal marketing $\rightarrow$ Commitment of resources \\
\hline $\begin{array}{c}\text { Medium } \\
\text { impact }\end{array}$ & $0 / 21$ & internal marketing $\rightarrow$ Internal branding \\
\hline $\begin{array}{c}\text { Medium } \\
\text { impact }\end{array}$ & $0 / 27$ & internal marketing $\rightarrow$ Green marketing performance \\
\hline $\begin{array}{c}\text { Medium } \\
\text { impact }\end{array}$ & $0 / 153$ & Commitment of resources $\rightarrow$ Green marketing performance \\
\hline $\begin{array}{c}\text { Medium } \\
\text { impact }\end{array}$ & $0 / 234$ & Internal branding $\rightarrow$ Green marketing performance \\
\hline
\end{tabular}

\section{Discussion and Conclusion}

Due to the increase of service organizations, competition for the survival of organizations has increased sharply and organizations must increase the quality of their services to compete. Employees have an important role to play in providing quality services and should be given special attention. Internal marketing and internal branding focus on employees, thereby helping to increase the quality of service. This research is also based on this common point (link between human resources and marketing). Employees in the service sector play an important role in promoting green marketing performance and creating a positive mental image of the organization due to direct interaction with customers. Internal retrieval is known as an internal tool to implement the organization's strategies that seeks to satisfy external customers through employees as internal customers of the organization. On the other hand, recently in the internal branding literature, which is rooted in internal marketing, has been recognized as a factor that leads to the fulfillment of employees' brand promises by influencing the attitude and behavior of employees. Internal branding has been proposed as a new approach in creating customer loyalty through the employee channel. Branding in the service sector is more dependent on the service providers of the organization due to special features of services such as intangibility, production and simultaneous consumption. In the present study, all structures were tested from the perspective of employees as internal customers of the evaluation organization. Among the results of path analysis, the highest path coefficient with a value of 0.51 internal marketing is on resource commitment. The value was 0.19 through the internal branding variable. The overall effect of the variable on the dependent variable of green marketing performance is 0.49 , of which 0.33 directly. 0.16 is a resource commitment through the mediating variable. The findings of this study are consistent with the results of research by Chang et al. (2018), Hernandez-Diaz et al. (2017), Zawahir et al. (2015), Forou et al. (2011) and Mashhadi Ramazan et al. (1398). 


\section{References}

Amit, R., \& Schoemaker, P. J. (2001). Strategic assets and organizational rent. Strategic Management Journal, 14(1), 33-46.

Aragón-Correa, J. A., Hurtado-Torres, N., Sharma, S., \& García-Morales, V. J. (2008). Environmental strategy and performance in small firms: A resource-based perspective. Journal of environmental management, 86(1), 88-103.

Baker, T. L., Hunt, T. G., \& Hawes, J. M. (1999). MARKETING STRATEGY AND ORGANIZATIONAL CULTURE: A CONCEPTUAL AND EMPIRICAL INTEGRATION. Journal of Marketing Management (10711988), 9(2).

Bigliardi, B., Bertolini, M., Mourad, M., \& Serag Eldin Ahmed, Y. (2012). Perception of green brand in an emerging innovative market. European Journal of Innovation Management, 15(4), 514-537.

Chan, E. S. (2013). Managing green marketing: Hong Kong hotel managers' perspective. International Journal of Hospitality Management, 34, 442-461.

Cheng, H.-H., \& Yang, H.-L. (2014). The antecedents of collective creative efficacy for information system development teams. Journal of Engineering and Technology Management, 33, 1-17.

Chin, W. W. (1998). The partial least squares approach to structural equation modeling. Modern methods for business research, 295(2), 295-336.Cheng, H.-H., \& Yang, H.L. (2014). The antecedents of collective creative efficacy for information system development teams. Journal of Engineering and Technology Management, 33, 1-17.

Gao T., Sirgy M. J., Johar J. S. (2010) "Developing a measure to capture marketing faculty's. perceptions of unethical behavior", Journal of Business Research, 63(1), pp. 366-371.

Jamnik A. (2011) "The question of ethical decision in marketing and ethics", Revista Cultura Economica, 80(1), pp. 41-53

Katler F., Armesterang G. (2008). Principles of Marketing, Translated by Frozande, B. Esfahan: Amokhte Press, p. 17

Khodadad Hosseini S. H., Khoddami S., Moshabbaki A. (2015) "The design of a model of market performance based marketing dynamic capabilities by operational agility approach", Journal of Management Research in Iran, 19(3), pp. 21-40

Kim, M., \& Chintagunta, P. K. (2012). Investigating brand preferences across social groups and consumption contexts. Quantitative Marketing and Economics, 10(3), 305-333.

Manrai, L. A., Manrai, A. K., \& Ryans Jr, J. K. (2009). How Green-Claim Strength and Country Disposition Affect Product Evaluation. Psychology \& Marketing, 14(5), 511-537

Majerova, J. (2015). Analysis of Slovak Consumer's Perception of the Green Marketing Activities. Procedia Economics and Finance, 26, 553-560. 